\title{
Örgütsel Destek, Örgütsel Özdeşleşme ve İşe Yabancılaşma Arasındaki Yapısal İlişkiler (Osmaniye İli Örneği)
}

\author{
Structural Relationships Between Organizational Support, \\ Organizational Identification, and Work Alienation (An \\ Example of Osmaniye Province)
}

\begin{abstract}
Selçuk DEMIR*
Öz: Örgütsel destek algısı, öğretmenlerin tutum ve davranışları üzerinde olumlu etkilere sahip önemli bir faktördür. $\mathrm{Bu}$ araştırmada; algılanan örgütsel destek ile öğretmenlerin örgütsel özdeşleşme ve işe yabancılaşma düzeyleri arasındaki ilişkinin tespit edilmesi amaçlanmıştır. Çalışma, nicel araştırma desenlerinden ilişkisel tarama modelinde tasarlanmıștır. Araştırmanın örneklemi; Osmaniye ilinde bulunan ilkokul, ortaokul ve liselerde görev yapmakta olan öğretmenler arasından küme örnekleme yöntemiyle tesadüfi olarak seçilmiş 35 okuldaki 231 öğretmenden oluşmaktadır. Araştırmanın veri seti; Algılanan Örgütsel Destek Ölçeği, Örgütsel Özdeşleşme Ölçeği ve İşe Yabancılaşma Ölçeği yardımıyla elde edilmiştir. Ölçüm modeli, değişkenlerin birbiriyle istatistiki olarak anlamlı ilişkilere sahip olduğunu göstermektedir. Yapısal eşitlik modellemesi sonuçları; algılanan örgütsel desteğin, öğretmenlerin örgütsel özdeşleşme düzeyi üzerinde istatistiki açıdan anlamlı ve negatif etkisi olduğunu göstermektedir. Algılanan örgütsel destek; öğretmenlerin işe yabancılaşma düzeylerini, örgütsel özdeşleşmenin tam aracılık etkisiyle negatif olarak etkilemektedir. Araştırma sonuçları esas alındığında; öğretmenlerin tutum ve davranışları üzerinde olumlu etki bırakabilmek için örgütsel destek algılarını güçlendirmeye yönelik uygulamalarda bulunulması gerekmektedir.
\end{abstract}

Anahtar Kelimeler: Örgütsel destek, örgütsel özdeşleşme, işe yabancılaşma, öğretmen

\begin{abstract}
The perception of organizational support is an important factor that has positive effects on teachers' attitudes and behaviors. The purpose of this research is to ascertain the relationship between perceived organizational support and teachers' level of organizational identification and work alienation. This study was designed by relational model, which is one of the quantitative methods. The sample comprises of 231 teachers in 35 schools that were randomly selected with cluster sampling method from primary, secondary and high schools in Osmaniye city. Dataset of the survey was gathered via Organizational Support Scale, Organizational Identification Scale and Work Alienation Scale. The measurement model indicates that study variables have statistically significant relationships with each other. The results of structural equation modeling reveal that perceived organizational support has a statistically significant and negative impact on teachers' level of organizational identification. Perceived organizational support negatively affects teachers' level of work alienation through the full mediation effect of organizational identification. Based on the consequences of this research, in order to be able to leave a positive impression on teachers' attitudes and behaviors, applications towards strengthening to their perceptions of organizational support are needed.
\end{abstract}

Keywords: Organizational support, organizational identification, work alienation, teacher

\section{Giriş}

Örgüt amaçlarının başarılı bir şekilde yerine getirilmesinde kuşkusuz birçok unsur rol oynamaktadır. Bu unsurlardan biri de çalışanların destek algılamalarıdır. Örgütsel destek, çalışanların dış çevreye uyum sağlamasına ve rekabet avantajı elde etmesine katkı sunmaktadır. Liu (2004) çalışmasında; örgütsel destek algısının, çalışanların tutum ve davranışlarını olumlu etkilediğini ortaya koymaktadır. Mercan (2015), çalışanların; örgütlerinin sunduğu katkıların karşıllı̆ııı verme zorunluluğunu hissettiklerini vurgulamaktadır. Örgütlerinde iyi ve olumlu

\footnotetext{
* Dr. Öğr. Üyesi, Şırnak Üniversitesi, Beden Eğitimi ve Spor Yüksekokulu, Şırnak-Türkiye, ORCID: 0000-0003-29046443, e-posta: selcukdemirs3@gmail.com
} 
davranışlarla karşılaşan çalışanlar; örgütsel uygulamalara katılma, özveri ile işlerine sahip çıkıp sorumluluklar alma, gönüllü olarak fazladan rol davranışlarında bulunma ve iş arkadaşlarına yardım etme gibi olumlu davranışlarda bulunarak örgütlerine karşılık vermektedirler (Liu, 2004; Dyne ve Ang, 1998). Tersi durumda ise sadece yapmaları gereken asgari sorumluluklar1 yerine getirmektedirler (Dyne ve Ang, 1998). Çalışanların örgütlerinde olumlu tutumlara sahip olması ve bu yönde davranışlar sergilemesi, kendilerini içinde bulundukları örgütün bir unsuru olarak algıladıklarının ve örgütlerini sahiplendiklerinin önemli göstergelerindendir (Karabey, 2005). Diğer bir anlatımla örgütsel destek algısı, çalışanların örgütleriyle özdeşleşmelerine katkı sunmaktadır. Örgütleriyle özdeşleşen çalışanların; işteki motivasyonları artmakta, örgütte kalma istekleri ve işlerine yabancılaşma düzeyleri azalmaktadır (İşbaş1, 2000). Bu gibi nedenlerden dolayı örgütler, çalışanların hem yüreklerinde hem de zihin dünyalarında yer bulmak istemektedirler (Sezici, 2015). Eğitim örgütleri özelinde düşünüldüğünde, öğretmenlerin örgütsel destek algısı denildiği zaman; kendilerini okullarının anlamlı bir unsuru olarak görmeleri, okulun amaçlarıyla bütünleşmeleri, okullarından kendilerini soyutlamamaları ve işlerine ilişkin ilgileri akla gelmektedir. $\mathrm{Bu}$ durumların doğal sonucu olarak, okullardaki eğitim ve öğretim faaliyetlerinin daha iyi bir nitelik kazanacağı düşünülmektedir.

\section{Örgütsel destek}

Eisenberger, Huntington, Hutchison ve Sowa (1986) örgütsel desteğin; örgüt değerlerinin, astların refahını gözetme ve onların daha mutlu olmalarını sağlayacak niteliklere sahip olma durumunu açıkladığını belirtmektedirler. Boyacı (2017) örgütsel destek algısının; çalışanların, örgütlerinin değer verdiğini algılamaları yoluyla örgütlerinde kendilerini güvende hissetmeleri olduğunu ifade etmektedir. Özdevecioğlu (2003) ise örgütsel destek alg1s1, bireylerin örgüt içerisinde güvende olduklarını ve örgütlerinin her zaman yanlarında olduğunu hissetmeleri şeklinde açıklamaktadır. Örgütsel destek; belirli bir olayda aniden oluşan bir durum olmayıp aksine, bireylerin zaman içerisinde örgütlerinden gördükleri iyi muameleler ya da katkılarla ilişkilidir (Çalışkan ve Pekkan, 2017). Örgütsel destek teorisine göre bireyler; örgütlerin sosyo-duygusal ihtiyaçların giderilmesinde ve gayretlerin ödüllendirilmesinde istekli olduğunu gördüklerinde, bu örgütlerde mutluluğa önem verildiğine ve çabaların takdir edildiğine dair inançlar oluşturmaktadırlar. $\mathrm{Bu}$ inançlar, örgütteki bireyler tarafından örgütsel destek olarak yorumlanmaktadır (Eisenberger ve diğerleri, 1986). Eğitim örgütlerinde öğretmenlerin değişiklikler konusunda önceden bilgilendirilmesi, kararlara katılımlarının sağlanması ve fikirlerinin dikkate alınması davranışları üzerinde şüphesiz olumlu bir etki bırakmaktadır. Çünkü öğretmenler, örgütleri tarafından desteklendiklerini algilamaktadırlar.

Örgütsel destek algısına sahip bireyler, diğerinin niyetinden ya da davranışlarından olumlu beklentiler içinde olmaktadırlar. Burada örgüt temsilcisine ya da yöneticisine güvenle ilişkili bir yapı ortaya çıkmaktadır (Mercan, 2015). Çünkü öğretmenler, okul yöneticilerine güvendiklerinde; okul yöneticilerinin öğretmenlerle ilişkilerinde yardımsever, dürüst, güvenilir, şeffaf ve yetkin, olduklarına inanmaktadırlar (Hoy ve Miskel, 2010). Diğer bir anlatımla öğretmenler, okul yöneticilerinin; kendileriyle ilişkilerinin sağlıklı olmasından dolayı niyetinden veya davranışından güven duymaktadır. Uzun (2018) örgütsel desteğin, öğretmenlerin örgütsel güvenini arttırdığını ortaya koymaktadır. Ayrıca bireyler, örgüt temsilcilerinden gördükleri olumlu davranışları; örgütlerine atfetmekte, onların iyiliğine ve katkılarına örgütleri tarafından değer verildiğinin ispatı şeklinde algılamaktadırlar (Mercan, 2015).

\section{Örgütsel özdeşleşme}

Ashforth ve Mael (1989, s. 22), örgütsel özdeşleşmeyi; birey ve örgüt amaçlarının artarak daha fazla bütünleşmesi ve uyumlaşması süreci, şeklinde tanımlamaktadır. Rousseau (1998, s. 217); örgütsel özdeşleşmenin, çalışanın kendisini bir bütünün parçası olarak algıladığı psikolojik bir durum olduğunu ileri sürmektedir. Bu psikolojik durum, çalışanın örgütüne yönelik tutum ve davranışlarının temelini oluşturmaktadır (Van Knippenberg ve Van Schie, 2000). Örgütleriyle özdeşleşen çalışanlar; örgütün amaçlarına ulaşması için daha fazla gayret göstermekte ve örgütün başarısının artması için uyumlu bir şekilde çalışmaktadırlar (Sezici, 2015). Örgütsel 
özdeşleşmenin bir diğer önemli yönü, çalışan ile örgüt arasındaki psikolojik ilişkiyi ortaya koymasıdır. Bu durum ise çalışanların önemli tutum ve davranışlarının kontrol edilebilmesine katkı sunmaktadır (Edwards, 2005). Bazı araştırmalarda, örgütsel özdeşleşmenin; iş tatmini (Çınar, Karcıoğlu ve Akdaş, 2016; Van Knippenberg ve Van Schie, 2000), örgütsel vatandaşlik davranışı (Karabey ve İşcan, 2007) ve işe sargınlık (Van Knippenberg ve Van Schie, 2000) ile olumlu; işten ayrılma niyeti (Abrams, Ando ve Hinkle, 1998; Çınar ve diğerleri, 2016; Turunç ve Çelik, 2010; Uzun, 2018) ile olumsuz yönde ilişkili olduğu görülmektedir. Bu yüzden yöneticiler, örgütteki üyelerin örgütle özdeşleşmelerini sağlamak için yoğun emek sarf etmektedirler (Sezici, 2015). Örgütsel özdeşleşmenin bir başka önemli yönü ise çalışanların; örgütsel amaç ve değerleri benimsemesine, içinde bulundukları örgütün bir parçası olduklarını algılamalarına ve yaptıkları işi anlamlı bulmalarına yardımcı olmasıdır (Van Dick, 2001). Bireyler; örgütlerinin amaç ve değerlerini benimsemediklerinde, örgütteki diğer üyelerin ilgisizliği ile karşılaşmaktadırlar. Biz ruhuyla hareket etmeyen bu bireyler, örgütlerinden soyutlanmakta ve örgütlerine yabancı bir unsur olmaktadırlar (Şimşek, Akgemci ve Çelik, 2011). Örgütle bu tür ilişkiler ise örgütsel amaç ve değerlere zarar vermekle sınırlı kalmamakta, aynı zamanda bireyin iş yaşamını da olumsuz etkilemektedir (Varoğlu ve Sığrı, 2014).

\section{İşe yabancılaşma}

İşe yabancılaşma; bireyin, psikolojik ve fiziksel olarak kendisini örgütünden soyutlaması ya da uzaklaşmasıdır (Demirez ve Tosunoğlu, 2017). Hirschfeld ve Feild (2000) ise işe yabancılaşmayı, çalışmaya ilişkin ilgi duymama olarak açıklamıştır. Örgütlerde üretkenlik karşıtı davranışlardan birinin yabancılaşma olduğu bilinmektedir (Varoğlu ve Sığrı, 2014). Yabancılaşma; güçsüzlük, anlamsızlık, yalıtılmışlık ve özsoğuma gibi farklı şekillerde görülebilmektedir. Bu durum çalışanlarda; yetersizlik hissi, işe gitmede isteksizlik, işbirliği yapamama, işte hata yapma, kararlarında tutarsızlık ve çalıştı̆̆ 1 kurumdan ayrılma gibi duygu ve davranışları ortaya çıkarabilmektedir (Şimşek ve diğerleri, 2011). Psikolojik açıdan mutsuz hisseden bireylerin, sahip olduğu bu duygu durumu iyi yönetilemediğinde iş performansları düşmekte (Varoğlu ve Sığrı, 2014), örgütlerine duygusal bağl1lıkları azalmakta (Hirschfeld ve Feild, 2000) ve iş stresleri artmaktadır (Demirez ve Tosunoğlu, 2017).

\section{Örgütsel destek ile örgütsel özdeşleşme ve işe yabancılaşma arasındaki ilişki}

Yüksek düzeyde örgütsel destek algılayan çalışanlar; düşük düzeyde örgütsel destek algılayan çalışanlarla kıyaslandığında, daha fazla örgütsel bağlılık hissetmekte ve sorumluluk almaya daha yatkın olmaktadır (Mercan, 2015). Zira önceki araştırmalarda (Boyacı, 2017; Uzun, 2018); algılanan örgütsel desteğin, öğretmenlerin örgütsel özdeşleşme düzeyleri ile pozitif yönde ilişkili olduğu bulunmuştur. Örgütünün desteğini arkasında hisseden bireyler, örgütlerinden ayrılmak istememekte ve işlerine daha sıkı bir şekilde bağlanmaktadırlar (Liu, 2004; Özdevecioğlu, 2003; Turunç ve Çelik, 2010). Bu konuda Çalışkan ve Pekkan (2017), algılanan örgütsel destek ile işe yabancılaşmanın negatif yönde ilişkili olduğunu ortaya koymuştur. Bireye içinde bulunduğu örgütü; destek, rahatlama ve iş ile ilgili çeşitli yardım ve tavsiyelerde bulunduğunda, birey işinden keyif almasa bile arkadaşlarından dolayı işinde mutluluk hissetmektedir. Birey, zamanla bu ortamda diğerleriyle birlikte başarılı olacağına inanmaktadır (Özkalp ve Kırel, 2010). Bireylerin örgütleriyle bütünleşmeleri, örgütlerinde daha enerjik olmalarını sağlamaktadır (Şimşek ve diğerleri, 2011).

İnsan yönetiminin esasında; verimlilik ortaya çıkarmak, kişisel gereksinimleri tespit etmek, olumsuz tutumları azaltmak ve daha üretken olunması için teşvik etmek vardır (Genç, 2012). Bu bağlamda incelenen örgütsel destek algısının, örgüte olduğu kadar bireylere de pek çok olumlu katkısı bulunmaktadır (Ceylan ve Şenyüz, 2003). Eğitim örgütlerindeki sınırlı sayıda çalışmanın olması, örgütsel desteğin; örgütsel özdeşleşme ve işe yabancılaşma gibi örgütler açısından çok önemli kavramlarla araştırılmasını gerektirmiştir. Zira bireyin, kendisini örgütten soyutlamasına ve üretim düzeyinin düşmesine yol açan işe yabancılaşmanın (Varoğlu ve Sığrı, 2014), azaltılmasına katkı sunan değişkenlerin ortaya çıkarılması önemli görülmektedir (Demirez ve Tosunoğlu, 2017). Bu araştırma değişkenleri arasındaki ilişkilerin ortaya konması; verimlilik, 
performans ve üretim açısından olumlu katkılar sağlayacaktır. Değişkenler arası ilişkilerin varlığına güçlü kanıtlar sunmak amaciyla yapısal bir model önerilmiştir. Örgütsel özdeşleşme algısının, örgütsel destek ile işe yabancılaşma algısı arasındaki ilişkide aracılık etkisi araştırılmıştır. Bu çalışmada, kavramlara ilişkin sağlıklı çıkarımlar yapılabilmesi mümkün hale getirilmiştir. $\mathrm{Bu}$ araştırmanın temel amacı, örgütsel destek algısı ile örgütsel özdeşleşme ve işe yabancılaşma arasındaki ilişkiyi belirlemektir. Araştırmada test edilen hipotezlere ilişkin model Şekil 1'de verilmektedir.

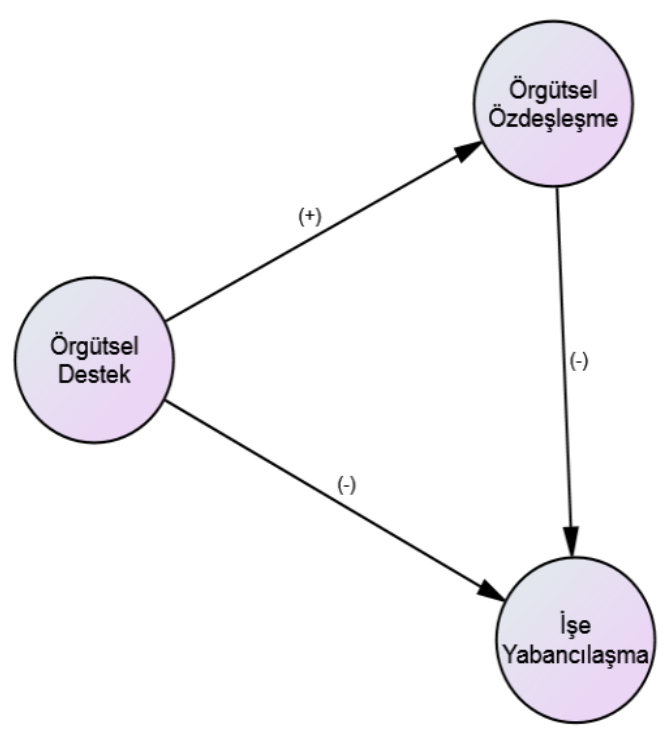

Şekil 1. Araştırma Çerçevesi

Araştırmanın temel amacı doğrultusunda test edilen hipotezler aşağıda belirtilmektedir:

H1: Örgütsel destek, örgütsel özdeşlemeyi pozitif olarak etkilemektedir.

H2: Örgütsel destek, işe yabancılaşmayı negatif olarak etkilemektedir.

H3: Örgütsel özdeşleşme, işe yabancılaşmayı negatif olarak etkilemektedir.

\section{Yöntem}

Bu çalışmada, nicel araştırma desenlerinden korelasyonel model kullanılmıştır. Öğretmenlerin; örgütsel destek, örgütsel özdeşleşme ve işe yabancılaşma değişkenlerine ilişkin algılarının ölçümü, yararlanılan ölçekler aracılı̆̆ıyla yapılmıştır. Araştırma değişkenleri arasında ilişkilerin birlikte değişim varlığı, yönü ve düzeyi tespit edilmiştir (Büyüköztürk, Çakmak, Akgün, Karadeniz ve Demirel, 2012).

\section{Örneklem}

Araştırmanın evrenini, Osmaniye ilindeki ilkokul, ortaokul ve liselerde görev yapmakta olan öğretmenler oluşturmaktadır. Bu çalışmada, oransız küme örnekleme yöntemi kullanılmıştır. 
Osmaniye'deki her okul bir küme olarak değerlendirilip 35 okul yansız olarak seçilmiştir. Bu okullarda görev yapmakta olan 231 öğretmen, araştırmanın örneklemini oluşturmaktadır.

\section{Veri toplama}

Veriler; Örgütsel Destek Ölçeği, Örgütsel Özdeşleşme Ölçeği ve İşe Yabancılaşma Ölçeği aracılığıyla toplanmıştır.

Araştırmada yararlanılan her bir ölçeğe ilişkin açımlayıcı faktör analizi (AFA), doğrulayıcı faktör analizi (DFA) ve güvenirlik analizi sonucu elde edilen istatistiki bilgiler aşağıda özet olarak sunulmaktadır.

Örgütsel Destek Ölçeği: Öğretmenlerin örgütsel destek algılarını tespit etmek için yararlanılan Örgütsel Destek Ölçeği; Eisenberger, Cummings, Armeli ve Lynch (1997) tarafindan geliştirilmiştir. Ölçeğin Türkçeye uyarlama çalışması, Akalın (2006) tarafından yapılmıştır. Ölçeğin, Bartlett Küresellik Testi sonucu anlamlı ve Kaiser-Meyer-Olkin (KMO) katsayısı .89 olarak bulunmuştur. AFA sonucunda ölçeğin tek boyuttan ve 8 maddeden oluştuğu görülmüştür. Ölçeğin tek boyutlu faktör yapısının, ölçme aracındaki toplam varyansın \%61.77'sini açıkladığ 1 tespit edilmiştir.

Örgütsel Özdeşleşme Ölçeği: Öğretmenlerin örgütsel özdeşleşme düzeylerini belirlemek için faydalanılan bu ölçek, Mael ve Ashforth (1992) tarafından geliştirilmiştir. Ölçeğin Türkçeye uyarlama çalışması, Tak ve Aydemir (2004) tarafından yapılmıştır. Ölçeğin Bartlett Küresellik Testi sonucunun anlamlı ve KMO katsayısının .84 olduğu belirlenmiştir. Ölçek, tek boyut ve 6 maddeden ibarettir. Ölçekteki tek boyutlu faktör yapısının, toplam varyansın \%77.21'ini açıkladığı tespit edilmiştir.

İşe Yabancılaşma Ölçeği: Bu ölçek, Hirschfeld, Feild ve Bedeian (2000) tarafından geliştirilmiş ve Kanten ve Ülker (2014) tarafından Türkçeye uyarlanmıştır. Ölçeğin; Bartlett Küresellik Testi sonucunun anlamlı ve KMO katsayısının .89 olduğu belirlenmiştir. Ölçeğin tek boyutlu faktör yapısı, 10 maddeden oluşmaktadır. Ölçeğin bu tek boyutlu faktör yapısının, ölçme aracındaki toplam varyansın \% 43.52'sini açıkladığ 1 tespit edilmiştir.

Bu araştırmada, kullanılan her bir ölçeğe ilişkin DFA sonucu elde edilen uyum değerleri, Tablo 1'de verilmiştir.

Tablo 1.

Ölçeklere İlişkin Uyum İyiliği Değerleri

\begin{tabular}{llllllllll}
\hline Ölçekler & $\mathrm{x} 2$ & $\mathrm{Sd}$ & $\mathrm{x} 2 / \mathrm{sd}$ & $\mathrm{p}$ & $\mathrm{GFI}$ & $\mathrm{IFI}$ & $\mathrm{TLI}$ & $\mathrm{CFI}$ & RMSEA \\
\hline Örgütsel Destek & 13.67 & 12 & 1.14 & .32 & .98 & .99 & .99 & .99 & .02 \\
Örgütsel Özdeşleşme & 11.17 & 8 & 1.39 & .19 & .98 & .99 & .99 & .99 & .04 \\
İșe Yabancilaşma & 17.23 & 14 & 1.23 & .24 & .98 & .99 & .98 & .99 & .03 \\
\hline
\end{tabular}

Tablo 1'e bakıldığında, x2 / sd oranın; örgütsel destek, örgütsel özdeşleşme ve işe yabancılaşma değişkenleri için 1 ile 2 arasında olduğu dolayısıyla iyi bir uyumun varlığı işaret edilmektedir. Araştırmadaki değişkenler için RMSEA değerinin 0.05 'in altında olduğu dolayısıyla iyi bir uyumun varlı̆ğ görülmektedir (Çelik ve Yılmaz, 2016). GFI değerinin .90'dan büyük olduğu dolayısıyla iyi uyumun olduğu anlaşılmaktadır (Kline, 2011; Meydan ve Şeşen, 2015). $I F I, T L I$ ve $C F I$ değerlerinin 0.95 'ten büyük olması ise iyi bir uyumun varlığını ortaya koymaktadır (Byrne, 2010; Kline, 2011). Ölçeklere uygulanan doğrulayıcı faktör analizleri sonucunda; her bir ölçeğin faktör yapısının, araştırma veri setiyle uyum değerlerinin iyi düzeyde olduğu görülmüştür.

Ölçeklerin faktör yapılarının uygunlukları kontrol edildikten sonra güvenirlik analizleri yapılmıştır. Ölçeklere uygulanan güvenirlik analizleri sonucunda, Cronbach’s Alpha Güvenirlik 
Katsayısı; Örgütsel Destek Ölçeği için .87, Örgütsel Özdeşleşme Ölçeği için .85 ve İşe Yabancılaşma Ölçeği için ise .84 olarak hesaplanmıştır.

İşlem

Ölçeklerin bulunduğu form, yansız olarak seçilen okullarda görev yapmakta olan öğretmenlere dağıtılmıştır. Katılımcılara; araştırmanın amacı, konusu ve değişkenleri hususlarında bilgi verilmiş olup çalışmaya katılımlarının tamamen gönüllülük ilkesine dayalı olduğu belirtilmiştir.

\section{Verilerin analizi}

Veriler, SPSS programına girilirken hatalı girişlerin ve eksik değerlerin olup olmadığı kontrol edilmiştir. Sonra Algılanan Örgütsel Destek ölçeğinde 2 tane ve İşe Yabancılaşma ölçeğinde 5 tane olmak üzere ters maddeler çevrilmiştir. Daha sonra verilerin uç değerler temizliği, çarpıklık ve basıklık katsayılarının kontrolü yapılmıştır. Tolerans ve VIF değerleri (Tolerans > .2, VIF < 10), bağımlı ve bağımsız değişkenler arasında çoklu bağlantı probleminin olmadığını ortaya koymuştur. "Gizil değiş̧kenlere yol analizi yapmak için test edilen modeldeki değişkenlerin ölçümüne yönelik kullanılan tüm ölçeklerin, geçerli ve güvenilir olması gerekmektedir" (Şimşek, 2007, s. 19). Araştırma verilerine, geçerlik ve güvenirlik açısından bakılmıştır. Faktör analizi sonuçları, araştırmada kullanılan ölçeklerin geçerli olduğunu göstermiştir. Güvenirlik analizi sonuçları ise ölçeklerin, güvenilir olduğunu ortaya koymuştur. Bu çalışmada, değişkenler arasındaki ilişkilere daha güçlü kanıtlar sunabilmek için ölçeklerin faktör uyumlarının araştırmanın veri setiyle sağlanmasının ardından sırasıyla ölçüm modeli ve yapısal model oluşturulmuştur.

Araştırmada kullanılan ölçeklerin her birinin DFA analiziyle üretilen uyum değerlerinin, araştırmalarda sıklıkla karşılan bazı kriterler açısından kontrolü yapılmıştır. Bu kriterler şu şekilde özetlenmektedir: $x_{2}$ / sd oran1 2'den küçük olduğunda iyi bir uyumun, 2 ile 5 arasında olduğunda ise kabul edilebilir bir uyumun bulunduğunu açıklamaktadır. RMSEA değerinin .08 ile .05 arasında olması kabul edilebilir, .05' den küçük olması ise iyi bir uyumun varlığı işaret etmektedir (Çelik ve Yılmaz, 2016). GFI değerinin; .85 ile .90 aralığında olması kabul edilebilir uyumun ve .90 'dan büyük olması iyi uyumun olduğuna işarettir (Meydan ve Şeşen, 2015). IFI, TLI ve CFI değerlerinin .90 ile .95 arasında olması kabul edilebilir bir uyumun, bu değerlerin .95 'in üstünde olması ise iyi bir uyumun bulunduğuna kanıttır (Byrne, 2010; Kline, 2011).

\section{Bulgular}

Araştırma değişkenlerine ilişkin betimleyici istatistikler (aritmetik ortalama, standart sapma ve standart hata) ile korelasyon katsayıları Tablo 2'de görülmektedir.

Tablo 2.

Betimsel İstatistikler ve Korelasyon

\begin{tabular}{lllllll}
\hline Değişkenler & $\overline{\mathrm{X}}$ & Ss & Std. Hata & 1 & 2 & 3 \\
\hline 1. Örgütsel Destek & 3.87 & .71 & .04 & 1 & & \\
2. Örgütsel Özdeşleşme & 3.56 & .80 & .05 & $.50^{* *}$ & 1 & \\
3. İşe Yabanc1laşma & 1.82 & .58 & .03 & $-.26^{* *}$ & $-.19^{* *}$ & 1 \\
\hline
\end{tabular}

$* \mathrm{p}<.05, * * \mathrm{p}<.01$

Tablo 2'ye bakıldığında, öğretmenlerin örgütsel desteğe ve özdeşleşmeye ilişkin algıları kısmen yüksek düzeyde (4: Katılıyorum) iken işe yabancılaşmaya ilişkin algıları kısmen düşük düzeydedir (2: Katılmıyorum). Korelasyon katsayıları incelendiğinde; örgütsel destek ile örgütsel özdeşleşme $(\mathrm{r}=.50, \mathrm{p}<.01)$ arasında orta düzeyde, pozitif ve anlamlı bir ilişki bulunmaktadır. Örgütsel destek ile işe yabancılaşma değişkenleri $(r=-.26, p<.01)$ zayıf düzeyde, negatif ve anlamlı ilişkilidir. Örgütsel özdeşleşme ile işe yabancılaşma $(\mathrm{r}=-.19, \mathrm{p}<.01)$ arasında çok zayıf düzeyde negatif ve anlamlı ilişki bulunmaktadır. Bu araştırmadaki değişkenlerin istatistiki açıdan 
birbiriyle anlamlı ilişkilere sahip olduğu görülmektedir. Elde edilen bu sonuç, ölçüm modelinde de araştırma değişkenlerinin birbiriyle anlamlı ilişkili olabileceğini düşündürmektedir.

Ölçüm modelinde, örtük değişkenlerin birbirleriyle ilişkileri Şekil 2'de görülmektedir.

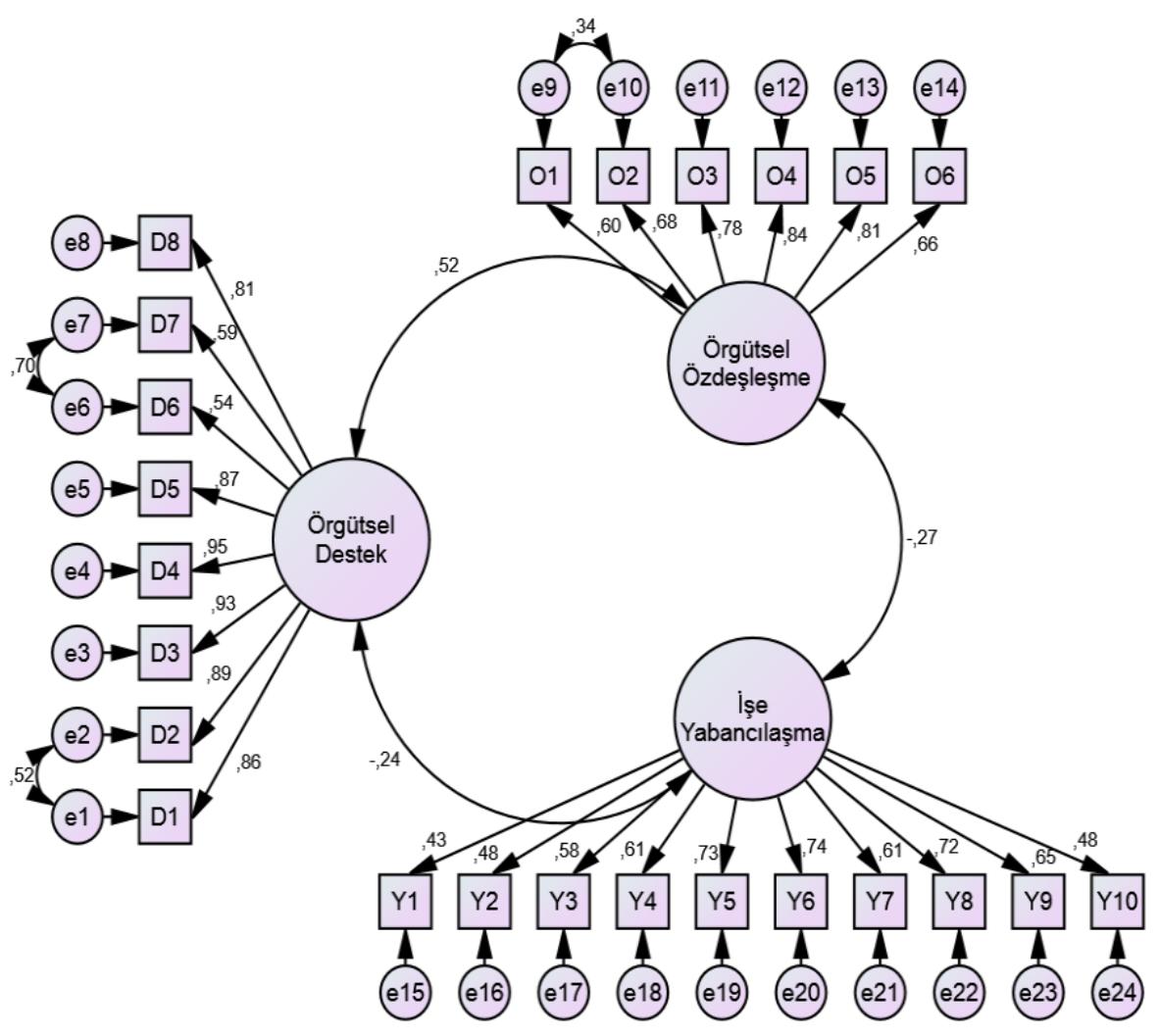

Şekil 2. Ölçüm Modeli

Ölçüm modelinde görüldüğ̈̈ üzere D6 ile D7, D1 ile D2 ve O1 ile O2 maddeleri arasına (bu maddelerdeki hataların birbiriyle ilişkili olmasından dolayı) hata kovaryansları eklenmiştir. Araştırma değişkenlerinin birbiriyle ilişkisinin anlamlı olduğu görülmüştür. Ölçüm modelinin, iyi düzeyde ve kabul edilebilir düzeyde ölçüm değerleri ürettiği görülmüştür ( $\mathrm{x} 2=483.86, \mathrm{sd}=246$, $\left.\mathrm{x}_{2} / \mathrm{sd}=1.97, \mathrm{p}=.00, \mathrm{GFI}=.85, \mathrm{IFI}=.93, \mathrm{TLI}=.92, \mathrm{CFI}=.93, \mathrm{RMSEA}=.06\right) . \mathrm{x} 2 / \mathrm{sd}$ oran 1 2 'den küçüktür (1.97) dolayısıyla bu uyum değeri iyi düzeydedir. GFI uyum indeksi .90'ın; IFI, TLI ve CFI uyum indeksleri ise .95 'in altında dolayısıyla bu indeksler kabul edilebilir düzeydedir.

Ölçüm modelindeki gizil değişkenler arasında eklenmiş olan kovaryanslar silinmiştir. Araştırmada test edilen hipotezler doğrultusunda gizil değişkenlere tek yönlü yollar eklenmiştir. Daha sıkı sonuçlar elde etmek için anlamsız bulunan yolların, önerilen modelden çıkarılması kararlaştırılmıştır. Önerilen modelde sadece Örgütsel Destek $\rightarrow$ İşe Yabancılaşma yolunun, anlamsız yol katsayısına sahip olduğu bulunmuş $(\mathrm{B}=-.05, \mathrm{~B}=-.13, \mathrm{p}=.11)$ ve bu yol modelden çıkarılmıştır.

Örgütsel Destek $\rightarrow$ İşe Yabancılaşma yolunun yapısal modelden silinmesine ilişkin uyum değerleri Tablo 2'de verilmektedir. 
Tablo 3.

Yapısal Modelde Anlamsız Yolların Silinmesi

\begin{tabular}{llllllllll}
\hline & $\mathrm{x} 2$ & $\mathrm{sd}$ & $\mathrm{x} 2 / \mathrm{sd}$ & $\Delta \mathrm{x} 2$ & GFI & IFI & TLI & CFI & RMSEA \\
\hline Doymuş model & 483.86 & 246 & 1.96 & - & .85 & .93 & .92 & .93 & .06 \\
$\begin{array}{l}\text { Örgütsel Destek } \rightarrow \text { İşe } \\
\text { Yabanc1laşma }\end{array}$ & 486.44 & 247 & 1.96 & .00 & .85 & .93 & .92 & .93 & .06 \\
\hline
\end{tabular}

Anlamsız yol katsayısının modelden silinmesi ile üretilen sonuçlar kısaca özetlendiğinde, x2/sd oranının 2'nin altında olduğu görülmektedir. Bu oran iyi bir uyumun işaretidir. GFI indeksi .85 dolayısıyla kabul edilebilir bir uyumun varlığı söz konusudur. IFI, TLI ve CFI değerlerinin .90 'ın üzerinde dolayısıyla bu durum kabul edilebilir bir uyumun olduğunun işaretidir.

Araştırmada anlamsız yol katsayısına sahip örgütsel destek $\rightarrow$ işe yabancılaşma yolu modelden çıkarıldıktan sonra elde edilen son yapısal eşitlik modeli Şekil 3'te görülmektedir.

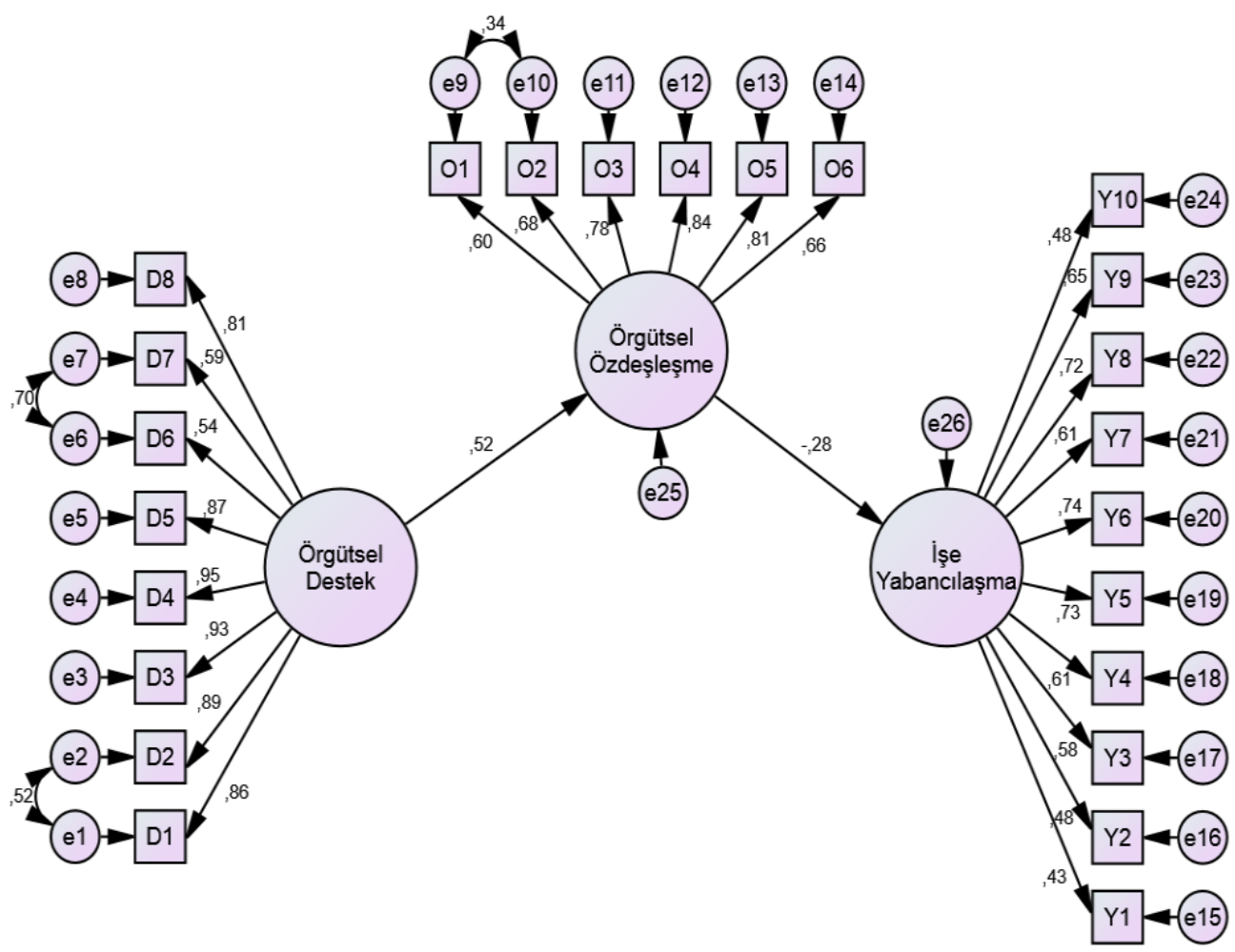

Şekil 3. Yapısal Eşitlik Modeli

En iyi uyum değerleri üreten $\left(\mathrm{x}_{2}=486.44, \mathrm{sd}=247, \mathrm{x} 2 / \mathrm{sd}=1.96, \mathrm{p}=.00, \mathrm{GFI}=.85\right.$, IFI $=.93, \mathrm{TLI}=.92, \mathrm{CFI}=.93, \mathrm{RMSEA}=.06$ ) yapısal eşitlik modeli incelendiğinde; algılanan örgütsel destek, öğretmenlerin örgütsel özdeşleşme düzeylerini pozitif olarak etkilemektedir $(B=$ $.52, \mathrm{p}<.01)$. Öğretmenlerin 1 birimlik örgütsel destek algısındaki artış, .52 birim örgütsel özdeşleşme algısındaki artışa katkı sunmaktadır. Örgütsel özdeşleşme, işe yabancılaşmayı negatif olarak etkilemektedir $(\beta=-.28, \mathrm{p}<.01) .1$ birim örgütsel özdeşleşme algısındaki artış, .28 birim işe yabancılaşma düzeyini azaltmaktadır. Algılanan örgütsel destek, işe yabancılaşmayı doğrudan etkilememektedir. Bununla birlikte algılanan örgütsel destek, örgütsel özdeşleşmenin tam aracılık etkisiyle işe yabancılaşmayı negatif olarak etkilemektedir $(B=-.15, p<.01)$. Örgütsel destek 
algısındaki 1 birimlik artış, dolaylı olarak (örgütsel özdeşleşmenin tam aracılığıyla). 15 birim öğretmenlerin işe yabancılaşma düzeyindeki azalışa yardımcı olmaktadır.

\section{Tartışma, Sonuç ve Öneriler}

Yapısal eşitlik modellemesi neticesinde, örgütsel destek algısının, örgütsel özdeşleşmeyi arttırdığ 1 belirlenmiştir. Dolayısıyla test edilen H1 hipotezi doğrulanmıştır. Algılanan örgütsel destek, öğretmenlerin işe yabancılaşma düzeyini doğrudan etkilememektedir. H2 hipotezi doğrulanmamıştır. Buna karşılık, örgütsel özdeşleşmenin, öğretmenlerin işe yabancılaşma düzeyini azalttığı tespit edilmiştir. Dolayısıyla önerilen H3 hipotezi doğrulanmıştır. Bunun yanı sıra algılanan örgütsel desteğin, öğretmenlerin işe yabancılaşma düzeyini, örgütsel özdeşleşmenin tam aracılık etkisiyle azalttığ 1 bulunmuştur.

$\mathrm{Bu}$ araştırmada; algılanan örgütsel desteğin, öğretmenlerin örgütsel özdeşleşme düzeylerini arttırdığı bulunmuştur. Benzer olarak önceki araştırmalarda (Boyacı, 2017; Uzun, 2018); örgütsel destek algısının, öğretmenlerin örgütsel özdeşleşmeleri ile pozitif ve anlamlı ilişkili olduğu ortaya koyulmuştur. Uzun (2018) ayrıca örgütsel güvenin; örgütsel destek algısının örgütsel özdeşleşme ve işten ayrılma niyeti üzerindeki etkisinde, kısmi aracılık rolünde olduğunu göstermiştir. Öğretmenlerin örgütlerinin niyetinden veya davranışlarından olumlu beklentilerinin olmas1, örgütleriyle bütünleşmelerine ve örgütte biz duygusu ile hareket etmelerine katk1 sağladığı görülmektedir. Eğitim örgütleri dışında yapılan araştırmada da (Turunç ve Çelik, 2010) örgütsel destek algısının, örgütsel özdeşleşme üzerinde pozitif bir etkisinin olduğu bulunmuştur.

Tuna ve Yeşiltaş (2014) çalışmasında; örgütsel özdeşleşme ile işe yabancılaşma arasında negatif yönlü, düşük düzeyde ve anlamlı bir ilişki bulmuşlardır. Bu araştırmada ise benzer olarak, algılanan örgütsel özdeşleşmenin, öğretmenlerin işe yabancılaşma düzeyini kü̧̈ük etki düzeyinde de olsa azalttığ1 tespit edilmiştir. Örgütleriyle psikolojik bağ kuran öğretmenler, örgütün amaçlarının gerçekleşmesi için büyük bir gayret ve uyum içerisinde çalıştıkları anlaşılmaktadır. Bu konuda Van Dick (2001) çalışmasında, bireylerin örgütleriyle özdeşleşmelerinin; örgütsel amaç ve değerleri benimsemelerine, örgütlerinin bir parçası olduklarını hissetmelerine ve işlerini anlamlı bulmalarına katkı sunduğunu vurgulamaktadır.

$\mathrm{Bu}$ araştırmada, algılanan örgütsel desteğin, işe yabancılaşmayı doğrudan etkilemediği tespit edilmiştir. Bunun yanı sıra örgütsel desteğin, örgütsel özdeşleşmenin kısmi aracılığıyla öğretmenlerin işlerine yabancılaşmalarını azalttığı ortaya çıkarılmıştır. Çalışkan ve Pekkan (2017); savunma sanayinde görev yapan bireylerle gerçekleştirdiği çalışmada, algılanan örgütsel desteğin işe yabancılaşmayı azalttığını bulmuştur. Liu (2004), büyük bir şirkette bilgi teknolojisinde çalışanlar ve onların doğrudan yöneticileriyle yürüttüğü çalışmasında, yüksek düzeyde algılanan örgütsel desteğin; çalışanların işten ayrılma niyetini azalttığını, çalışanlarda örgütlerine karşılık verme hissi oluşturarak onların örgütsel bağll1ıklarını, örgütsel vatandaşlık davranışını ve iş performansını arttırdığını tespit etmiştir. Bu araştırmada, algılanan örgütsel desteğin, işe yabancılaşmayı doğrudan etkilemediği bulgusu, Çalışkan ve Pekkan (2017) tarafından yapılan araştırma sonucu ile farklılık göstermektedir. Bunun yanı sıra şimdiki araştırmada, örgütsel desteğin, örgütsel özdeşleşmenin kısmi aracıllğıyla öğretmenlerin işlerine yabancılaşmalarını azalttı̆ğ bulunmuştur. Liu (2004) tarafından yürütülen çalışmanın sonucuna bakıldığında, aracılık etkisiyle bir kısım önemli iş çıktılarının (örgütsel bağlılık, örgütsel vatandaşlık davranışı ve iş performansı) elde edildiği görülmektedir. Bu tür olumlu tutumlara sahip çalışanların ise işlerine yabancılık hissetmeyecekleri, aksine işlerine daha ilgili olacakları şüphesizdir. Dolayısıyla bu çalışmada aracılık etkisiyle örgütsel desteğin, öğretmenlerin işleriyle ilgilenmelerini arttırdığı görülmektedir. Nitekim yabancılaşma hisseden bireylerin, iş performanslarının düştüğü (Varoğlu ve Sığrı, 2014) ve örgütlerine duygusal bağl1l1klarının azaldığ 1 (Hirschfeld ve Feild, 2000) bilinmektedir.

Yararlanılan ölçeklerin tek boyutlu faktör yapısında olmaları, bu araştırmanın bir sınırlılığ1 olarak görülebilir. Diğer bir sınırlılığı ise araştırmanın sadece bir ilde ve kısıtlı bir örneklem grubunun ölçek maddelerine verdikleri yanıtlarla gerçekleştirilmiş olmasıdır. Araştırmanın bu sınırlılıklarına rağmen özellikle eğitim örgütlerinde, öğretmenlerin nitelik ve verimliliği arttırıcı iş çıktılarını arttırabilen insan kaynaklarına ilişkin uygun ve yerinde 
uygulamaların belirlenmesi ve hayata geçirilmesine katkı sunmaktadır. Bu araştırma farklı araştırma desenleriyle tekrar edilebilir. İleriki çalışmalarda, özellikle eğitim örgütlerinde örgütsel desteğin işe yabancılaşma üzerindeki etkisine yönelik aracı değişken olarak örgütsel özdeşleşme yerine örgütsel güven ve adanmışlık gibi farklı örgütsel davranış değişkenleri test edilebilir.

\section{Kaynaklar}

Abrams, D., Ando, K. ve Hinkle, S. (1998). Psychological attachment to the group: Cross-cultural differences in organizational identification and subjective norms as predictors of workers' turnover intentions. Personality and Social Psychology Bulletin, 24(10), 1027-1039. doi.org/10.1177/01461672982410001

Akalın, Ç. (2006). Duygusal örgütsel bağgllık gelişiminde çalışanların algıladı̆̆ı örgütsel destek ve ara değişken olarak örgüt temelli özsaygı (Yayımlanmamış yüksek lisans tezi). Sosyal Bilimler Enstitüsü, Hacettepe Üniversitesi, Ankara.

Ashforth, B. E. ve Mael, F. (1989). Social Identity Theory and the organization. Academy of Management Review, 14(1), 20-39.

Boyac1, A. (2017). Öğretmenlerin algllanan örgütsel destek ve örgütsel özdeşleme düzeylerinin veri madenciliği ile analizi (Yayımlanmamış yüksek lisans tezi). Sosyal Bilimler Enstitüsü, Hitit Üniversitesi, Çorum.

Büyüköztürk, Ş., Çakmak, E. K., Akgün, Ö. E., Karadeniz, Ş. V. ve Demirel, F. (2012). Bilimsel araştırma yöntemleri. Ankara: Pegem Akademi.

Byrne, B. M. (2010). Structural equation modeling with AMOS. New York: Routledge.

Ceylan, A. ve Şenyüz, B. (2003). Örgütsel destek algısı ve dahil olma-dışlanmama algısının örgütsel bağlılığa etkisi-Sigorta sektöründe bir araştırma. Yönetim, 44, 57-62.

Çalışkan, A. ve Pekkan, N. Ü. (2017). Psikolojik sermayenin işe yabancılaşmaya etkisinde örgütsel desteğin arac1lık rolü. İş ve İnsan Dergisi, 4(1), 17-33. doi: 10.1e8394/iid.303183

Çelik, H. E. ve Yılmaz, V. (2016). Lisrel 9.1. ile yapısal eşitlik modellemesi, Temel kavramlarUygulamalar- Programlama. Ankara: An1.

Çınar, O., Karcıoğlu, F. ve Akdaş, K. (2016). İş yaşamında iş tatmini, örgütsel özdeşleme ve işten ayrılma niyeti ilişkisi: Erzurum'da bir kamu kurumu örneği. Siyaset, Ekonomi ve Yönetim Araştırmaları Dergisi, 4(3), 121-136.

Demirez, F. ve Tosunoğlu, N. (2017). Örgüt ikliminin işe yabancılaşma üzerine etkisi: Gazi Üniversitesi Rektörlügünde bir araştırma. İşletme Araştırmaları Dergisi, 9(2), 69-88. Doi: 10.20491/isarder.2017.262

Dyne, L. V. ve Ang. S. (1998). Organizational citizenship behavior of contingent workers in Singapore. The Academy of Management Journal, 41(6), 692-703.

Edwards, M. R. (2005). Organizational identification: A conceptual and operational review. International Journal of Management Reviews, 7(4), 207-230.

Eisenberger, R., Cummings, J., Armeli, S. ve Lynch, P. (1997). Perceived organizational support, discretionary treatment, and job satisfaction. Journal of Applied Psychology, 82, 812-820.

Eisenberger, R., Huntington, R., Hutchison, S. ve Sowa, D. (1986). Perceived organizational support. Journal of Applied Psychology, 7, 500-507.

Genç, N. (2012). Yönetim ve organizasyon: Çağdaş sistemler ve yaklaşımlar. Ankara: Seçkin.

Hirschfeld, R. R. ve Feild, H. S. (2000). Work centrality and work alienation: Distinct aspects of a general commitment to work. Journal of Organizational Behavior, 21(7), 789-800. doi.org/10.1002/1099-1379(200011)21:7<789::AID-JOB59>3.0.CO;2-W

Hirschfeld, R. R., Feild, H. S. ve Bedeian, A. G. (2000). Work alienation as an individualdifference construct for predicting workplace adjustment: A Test in two samples. Journal of Applied Social Psychology, 30 (9), 1880-1902.

Hoy, W. K. ve Miskel, C. G. (2010). Eğitim yönetimi: Teori, araştırma ve uygulama. (Çev. ed. Turan, S.). Ankara: Nobel Yayın Dağıtım.

İşbaşı, Ö. J. (2000). Çalışanların yöneticilerine duydukları güvenin ve örgütsel adalete ilişsin algılamalarının örgütsel vatandaşlık davranışının oluşumundaki rolü: Bir turizm 
örgütünde uygulama (Yayımlanmamış yüksek lisans tezi). Sosyal Bilimler Enstitüsü, Akdeniz Üniversitesi, Antalya.

Kanten, P. ve Ülker, F. (2014) Yönetim tarzının üretkenlik karşıtı iş davranışlarına etkisinde işe yabancılaşmanın aracılık rolü. Muğla Sttkı Koçman Üniversitesi Sosyal Bilimler Enstitüsü Dergisi, 32, 16-40.

Karabey, C. N. (2005). Örgütsel özdeşleşme, örgütsel imaj ve örgütsel vatandaşlık davranışı ilişkisi: Bir uygulama (Yayımlanmamış yüksek lisans tezi). Sosyal Bilimler Enstitüsü, Atatürk Üniversitesi, Erzurum.

Karabey, C. N. ve İşcan, Ö. F. (2007). Örgütsel özdeşleşme, örgütsel imaj ve örgütsel vatandaşlık davranışı ilişkisi: Bir uygulama. Atatürk Üniversitesi İktisadi ve İdari Bilimler Dergisi, 21(2), 231-241.

Kline, R. B. (2011). Principles and practice of structural equation modeling. New York: The Guilford Press.

Liu, W. (2004). Perceived organizational support: Linking human resource management practices with important work outcomes (Dissertation of Doctor of Philosophy). University of Maryland.

Mael, F. ve Ashforth, B.E. (1992), Alumni and their alma mater: A partial test of the reformulated model of organizational identification, Journal of Organizational Behavior, 13(2), 103123.

Mercan, N. (2015). Örgütsel yaşamda yalnızlık. D. E. Özler (Yay.haz.), Örgütsel davranışta güncel konular içinde (ss. 429-452). Bursa: Ekin Basım Yayın Dağıtım.

Meydan, C. H. ve Şeşen, H. (2015). Yapisal eşitlik modellemesi, Amos uygulamaları. Ankara: Detay.

Özdevecioğlu, M. (2003). Algılanan örgütsel destek ile örgütsel bağl1lık arasındaki ilişkilerin belirlenmesine yönelik bir araştırma. Dokuz Eylül üniversitesi İktisadi ve İdari Bilimler Dergisi, 18(2), 113-130.

Özkalp, E. ve Kırel, Ç. (2010). Örgütsel davranış. Bursa: Ekin Yayınevi.

Rousseau, D. M. (1998). Why workers still identify with organizations. Journal of Organizational Behavior, 19, 217-233.

Sezici, E. (2015). Örgütsel özdeşleşme. D. E. Özler (Yay. haz.), Örgütsel davranışta güncel konular içinde (ss. 167-194). Bursa: Ekin Basım Yayın Dağıtım.

Şimşek, Ö. F. (2007). Yapısal eşitlik modellemesine giriş. Temel ilkeler ve Lisrel uygulamaları. Ankara: Ekinoks.

Şimşek, M. Ş., Akgemci, T. ve Çelik, A. (2011). Davranış bilimlerine giriş ve örgütlerde davranıs. Ankara: Gazi Kitabevi.

Tak, B. ve Aydemir, B. A. (2004). Örgütsel özdeşleşme üzerine iki görgül çalışma. 12. Ulusal Yönetim ve Organizasyon Kongresi Bildiri Kitab1. Bursa: Uludağ Üniversitesi.

Tuna, M. ve Yeşiltaş, M. (2014). Etik iklim, işe yabancılaşma ve örgütsel özdeşleşmenin işten ayrılma niyeti üzerindeki etkisi: Otel işletmelerinde bir araştırma. Anatolia: Turizm Araştırmaları Dergisi, 25(1), 105-117.

Turunç, Ö. ve Çelik, M. (2010). Algılanan örgütsel desteğin çalışanların iş-aile, aile-iş çatışması, örgütsel özdeşleşme ve işten ayrılma niyetine etkisi: savunma sektöründe bir araştırma. Atatürk Üniversitesi Sosyal Bilimler Enstitüsü Dergisi, 14(1), 209-232.

Uzun, T. (2018). Öğretmenlerin alg1ladığı örgütsel destek ile örgütsel özdeşleşme ve işten ayrılma niyeti arasındaki ilişki: Örgütsel güvenin aracı rolü. Karadeniz Sosyal Bilimler Dergisi, 10(18), 133-155.

Van Dick, R. (2001). Identification in organizational context: Linking theory and research from social and organizational psychology. International Journal of Management Reviews, 3(4), 265-283.

Van Knippenberg, D. ve Van Schie, Els C. M. (2010). Foci and correlates of organizational identification. Journal of Occupational and Organizational Psychology, 73, 137-147. 
Varoğlu, D. ve Sığrı, Ü. (2014). Örgütsel davranışın karanlık yüzü: İşyerinde üretkenlik karşıtı davranışlar. Ü. Sığrı ve S. Gürbüz (Yay. haz.). Örgütsel davranış içinde (ss. 673-704). İstanbul: Beta Basım Yayım Dağıtım.

\section{Extended Abstract}

\section{Introduction}

The principal of human management is to reveal productivity, to detect personal needs, to reduce negative attitudes and to stimulate much more productive (Genç, 2012). In this sense, the analyzed organizational support perception has many positive contributions not only to individuals but also to the organization (Ceylan \& Şenyüz, 2003). The insufficiency of studies in educational organizations has made it required to investigate some crucial concepts such as organizational identification and work-alineation. Forasmuch as, it has been seen important to reveal the variables that contribute to the reduction of alienation from the work (Varoğlu \& Siğrı, 2014), that cause the individual to isolate himself from the organization and decrease the level of production (Demirez \& Tosunoğlu, 2017). In this research, to deduce the relationships among variables will contribute positive effects in terms of productivity, performance and yieldance. A structural model has been offered to present strong evidences for the presence of the correlations among variables. The mediation effect of the organizational identification in the relationship between organizational support and work alienation perception has been explored. In this study, it has been made possible to make healthy inferences about concepts. The main purpose of this study is to determine the relationships between organizational support perception and organizational identification and work alienation.

The hypotheses tested in line with the main purpose of the research are as follows:

H1: Organizational support positively influences organizational identification.

$\mathrm{H} 2$ : Organizational support negatively influences work alienation.

H3: Organizational identification negatively influences work alienation.

\section{Method}

Correlation model, one of the quantitive research patterns has been utilized in this research. Teachers' perceptions towards organizational support, organizational identification and work alienation variables have been measured through the scales used. The universe of the research has been composed of teachers working in primary, secondary and high schools in Osmaniye. Disproportionate cluster sampling method has been utilized in this study. Each school in Osmaniye has been perused as a cluster and 35 schools have been selected objectively. 231 teachers who are on duty in these schools have formed the sampling of this research.

Data has been obtained by Organizational Support Scale, Organizational Identification Scale and Work Alienation Scale.

Organizational Support Scale: Organizational Support Scale, which has been utilized to determine the organizational support perceptions of teachers has been developed by Eisenberger, Cummings, Armeli and Lynch (1997). Turkish adaption study of the scale has been done by Akalın (2006). As a result of AFA, it has been seen that the scale consists of one dimension and 8 items.

Organizational Identification Scale: Organizational Identification Scale, which has been utilized to determine the organizational identification level of teachers has been improved by Mael and Ashforth (1992). Turkish translation study of the scale has been performed by Tak and Aydemir (2004). The scale has formed from one dimension and 6 items.

Work Alienation Scale: This scale has been developed by Hirschfeld, Feild and Bedeian (2000) and has been adapted to Turkish by Kanten and Ülker (2014). One-dimensional factor structure of the scale has comprised of 10 items. 
As a result of confirmatory factor analysis applied to the scales, it has been seen that the factor structure of each scale and the compliance values with the research data set are good. After checking the suitability of factor structure of the scales, reliability analyzes have performed. After reliability analyzes utilized to scales, Cronbach's Alpha Coefficient has been calculated as .87 for Organizational Support Scale, .85 for Organizational Identification Scale and .85 for Work Alienation Scale.

\section{Result and Discussion}

It has been identified in the conclusion of structural equation modeling that organizational support perception rears organizational identification. That's to say, tested H1 hypothesis is confirmed. Perceived organizational support does not directly affect work alienation level of teachers. H2 hypothesis cannot be confirmed. On the other hand, it has been detected that organizational identification decreases work alienation level of teachers. So, suggested H3 hypothesis is confirmed. Moreover, it has been found out that perceived organizational support decreases work alienation level of teachers through the full mediation effect of the organizational identification.

One-dimensional factor structure of the scales used can be seen as a limitation of this study. One other limitation is that this study has been performed in only one city and realized according to responses of a limited sample group to the scale items. In spite of these limitation of this study, especially in educational organizations, this study contributes to the identification and implementation of appropriate and on-site practices related to human resources that can increase teachers' quality and productivity-enhancing work outcomes. This study can be repeated with different research patterns. In further studies, particularly educational organizations, for the effect of the organizational support on work alienation level, some other variables such as organizational trust and commitment can be tested as a mediator variable in place of organizational support. 